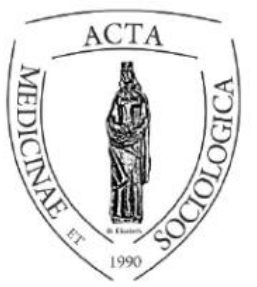

Acta Medicinae et Sociologica (2021)

Vol. 12. No. 32. (67-88)

UNIVERSITY OF

DEBRECEN

doi:

FACULTY OF

HEALTH

https://doi.org/10.19055/ams.2021.05/31/4

NYÍREGYHÁZA

\title{
Az iskolai szegregáció szerepe a hátrányos helyzetü gyermekek és fiatalok lemaradásában ${ }^{1}$
}

Bihari Ildikó $^{2}$

${ }^{2}$ Egyetemi tanársegéd, Debreceni Egyetem, Szociológia és Szociálpolitika Tanszák; doktorandusz, Humán Tudományok Doktori Iskola Szociológia és társadalompolitika doktori program

INFO ABSTRACT

\section{Bihari Ildikó}

bihari.ildiko@arts.unideb.hu

\section{Keywords}

disadvantage, Roma students, school segregation, skill deficit, cognitive development

\begin{abstract}
The role of school segregation in the disadvantaged children and young people]: Experts have long studied the relationship between school segregation and unequal opportunity for students from disadvantaged backgrounds. Drawing on academic literature, research and statistical data, this paper examines the consolidation of school segregation in the country, the impact of segregation on the learning achievement of disadvantaged students in public education and on intergroup relations. The issue of educational segregation and integration is often a subject of debate, but research evidence favours heterogeneous composition to foster students' school careers, future labour market prospects and social inclusion.
\end{abstract}

\section{Kulcsszavak}

hátrányos helyzet, roma tanulók,

Absztrakt: A szakértők régóta vizsgálják az iskolai szegregáció és a hátrányos helyzetű diákok iskolai szegregáció, készségdeficit, esélyegyenlőtlenségének kapcsolatát. A tanulmány a kognitív fejlődés szakirodalmak, kutatások és statisztikai adatok alapján vizsgálja az iskolai szegregáció hazai megszilárdulását, a szegregáció hatását a köznevelési intézményben

\footnotetext{
${ }^{1}$ Ez a tanulmány az EFOP-3.6.3-VEKOP-16-2017-00007 - „Tehetségből fiatal kutató” - A kutatói életpályát támogató tevékenységek a felsőoktatásban pályázat támogatásával készült.
} 


tanuló hátrányos helyzetű diákok tanulási
teljesítményére és a csoportközi kapcsolatokra
vonatkozóan. Az oktatási szegregáció és integráció
kérdésköre gyakran vita téma, a kutatási tapasztalatok
azonban a heterogén összetételt preferálják a diákok
iskolai pályafutása, jövőbeli munkaerőpiaci esélyei és
a társadalmi integráltság erősítése céljából.

\section{Bevezetés}

Számos hazai és nemzetközi vizsgálat igazolta, hogy a hátrányos helyzetü diákok többsége - akik között Magyarországon magas a cigány származásúak aránya (Szücs 2010) - szociokulturális környezetük/hátterük miatt alulteljesítenek az iskolában. Napjaink megoldandó társadalmi problémája a szegény, alacsony iskolázottságú hátrányos helyzetü, főként roma családok tanulóinak a köznevelési intézményekben ért sikertelenségeiknek és deficitjeinek a kompenzálása a munkaerőpiaci és társadalmi szegregáció, valamint az underclass-élethelyzet generációk közötti átörökítésének mérséklése érdekében (Szücs 2010, Liskó 2009). Az alulteljesítés egyik fő oka az iskolai szegregációval magyarázható (Kertesi és Kézdi 2012). Az iskolai kudarcok következményeként számolni kell a munkaerőpiaci kudarcokkal, mely hosszú távon alakítja az érintettek életminőségét, (munkával való) elégedettségét (R. Fedor 2021), ráadásul a munkaeröpiacon megjelenő általános egyenlőtlenségek hangsúlyosabban jelennek meg az egyébként is hátrányos helyzetü roma munkavállalói csoportoknál (R. Fedor és Balla 2019).

Az oktatási rendszerünk egyenlőtlen esélyeket biztosít a diákok számára, szelektív és szegregált oktatást folytat. A 2000-res évek óta a háromévenkénti PISA vizsgálatok eredményei igazolják, hogy hazánkban iskolaszinten és osztályszinten is jelentős mértékben elkülönülnek egymástól a könnyen tanítható, jó képességü, középosztályhoz tartozó tanulók és a tanulási nehézségekkel küzdő, problémás, nehezen tanítható, szegény és iskolázatlan családok gyermekei (Balázsi, Szabó és Szalay 2005, Csapó, Molnár és Kinyó 2009, Kertesi és Kézdi 2009, Ostorics és mtsai 2016). A tanulmány célja azt elemezni, hogy a szegregált oktatási formának milyen szerepe van a tanulmányi lemaradásban, hogyan gátolja a készségek fejlődését, a hátrányos helyzetủ diákok felzárkóztatását és integrációját. A tanulmányban áttekintjük az iskolai szegregáció és integráció fogalmát, típusait és jelentőségét, majd ismertetjük az iskolai szegregáció jelenségnek folyamatát, megszilárdulását és a szegregáció hatását a tanulói teljesítményre és a csoportközi kapcsolatokra. 


\section{Szegregáció kontra integráció}

Az oktatás területén a szegregáció és az integráció egymás ellentétpárja. A fogalompár az 1950-es és 60-as években került a társadalomtudományos vizsgálatok fókuszába az afro-amerikaiak szegregációja révén (Dupcsik 2012). Az amerikai szakirodalom meghatározása szerint az iskolai szegregáció a tanulók nem önkéntesen vállalt, eltérő tulajdonságok (vallás, nem, fizikai, mentális hátrány), illetve faji, etnikai alapú elkülönítését jelenti, melynek következtében fehér és fekete iskolák jönnek létre (Szücs 2010).

Az integrációs és szegregációs diskurzus az európai országokban, köztük hazánkban is megjelent és a fogalmat kezdetben leginkább a társadalmi kisebbséghez tartozó és a fogyatékkal élő diákok oktatási kérdéseivel kapcsolatosan használták, majd megalakult a sajátos nevelési igényü (SNI) fogalom, amelybe beleintegrálták a szociális helyzetük, etnikai hovatartozásuk alapján szegregált, hátrányt szenvedő tanulócsoportokat és a fogyatékosokat is. A hazai jogszabályok - 2003-as Közoktatási Törvény 121. § (1) 29. pontja, illetve a Köznevelési Törvény az Országgyülés által 2012. július 12-én elfogadott módosítása (2012/CXXXIV. tc. 1 § 25. pontja) - alapján a sajátos nevelési igényü kategóriába kizárólag csak a szervi/értelmi fogyatékossággal, és pszichés zavarokkal küzdő diákok tartoznak bele, és a hátrányos helyzetü, illetve diszkriminált csoportok nem (Dupcsik 2012: 247). Ugyanakkor Dupcsik (2012) megjegyzi, hogy mind a szociológiában, mind a mindennapi szóhasználatban az integrált oktatás kiterjed a szervi/pszichés okokból vagy tanulási zavarok miatt SNI-nek minősített, és a szociális/etnikai helyzetük miatt szegregáció veszélyének kitett, föként roma tanulókra is.

Kertesi és Kézdi szerzőpáros az iskolai szegregáció fogalmi meghatározásakor a szociális hátrányt emeli ki: ,,alacsony státusú családok gyermekeinek lakóhelyi elkülönülésük mértékét meghaladó elöfordulása bizonyos típusú iskolákban vagy egy iskolán belül bizonyos típusú osztályokban" (Kertesi és Kézdi 2005: 317318). Havas (2008: 122) megfogalmazása szerint „, a szegregáció, a halmozottan hátrányos helyzetü és különösen a roma gyermekek iskolai elkülönitése, ami egyszerre oka és következménye a polarizációnak”. A szerző meghatározásában hangsúlyozza a cigány tanulók etnikai alapú diszkriminálását is az iskolákban. Dupcsik fogalommeghatározása részben lefedi a fentebb említett szerzők definícióját, ezért a dolgozatban a szerző megfogalmazását használom, mely szerint a szegregáció a ,hátrányos helyzetü és/vagy diszkrimináció esélyének kitett csoportok gyermekeinek elkülönült oktatása” (Dupcsik 2012: 244). 
A szegregációnak két típusát különbözteti meg a szakirodalom: az elkülönítést és az elkülönülést. Az elkülönítés tudatos külső beavatkozás eredményeként jön létre, melynek az egyik formája az iskolán belüli szegregáció (pl. tagozatok és osztályok közötti, illetve osztályon belüli elkülönítés, tanórán kívüli foglalkozások, magántanulóvá nyilvánítás) és a másik az iskolarendszeren belüli, azaz az iskolák közötti szegregáció (pl. települések közötti, illetve intézményi szintü elkülönítés, indokolatlan fogyatékossá/SNI tanulóvá nyilvánítás gyakorlata) (Gerö, Csanádi és Ladányi 1996, Fiáth 2002, Havas, Kemény és Liskó 2002, Arató, Horváth és Varga 2005, Hermann és mtsai 2009, Liskó és Havas 2005, Szücs 2010, Fónai 2020).

Kezdetekben az óvodai/iskolai szegregáció és integráció kérdéskörét úgynevezett orvosi modell keretei között képzelték el, amely modell végül pedagógiai modellé nőtte ki magát. Az orvosi modell abból indul ki, hogy a problémát maga a gyermek okozza, és a diagnózis felállítását követően a „betegeket” elkülönítik vagyis szegregálják az „egészségesektől”. A pedagógiai modell ellenben más szemléletben gondolkodik. A két modell közötti különbséget az eltérő szemlélet adja. A pedagógiai modell a sikertelenség okát nem a gyermekben, hanem a környezetben keresi. Az oktatási intézményrendszer merev müködése helyett az alkalmazkodásra épít, valamint nem a hiányosságot hangsúlyozza, hanem fejleszt (Jönsson 1993).

„Az integrált iskola egyenlö tanulási feltételeket és eredményeket biztosit, minden tanulót faji és társadalmi származástól függetlenül, egyenlö hatékonysággal tanit. Így minden integrált iskola deszegregált, de nem minden deszegregált iskola integrált” (Szücs 2010: 14). A szakirodalmak alapján azt tapasztaltuk, hogy az integrált oktatás koncepciójának képviselői sem egységesen gondolkodnak az integráció gyakorlati megvalósítási formájáról. Továbbá az integráció fogalma folyamatosan új tartalommal bövül. ${ }^{2}$

Az integrált oktatás koncepció mellett érvelő Csányi (2001) az integráció egy fejlettebb szintjét hangsúlyozza. Az integráció három - lokális, szociális, funkcionális - fajtáját különböztette meg (Lásd. 1. sz. ábra). Azt az álláspontot hangsúlyozza, hogy az integráció lényege nem az, hogy a különböző kategóriába sorolt diákok egy iskolában tanulnak, de különböző osztályokban, mert az csak az integráció legalacsonyabb, úgynevezett lokális szintje. A lokális integráció

\footnotetext{
${ }^{2} \mathrm{Az}$ integráció fogalmát a szakirodalom kezdetben a fogyatékos, majd az SNI diákokkal kapcsolatosan használja. Az SNI diákok fogalmi meghatározásban bekerültek a hátrányos helyzetü diákok is. A keretek tartása miatt külön a fogyatékos diákok integrációjára nem térünk ki.
} 
leginkább a fizikai távolság csökkentésére alkalmas, de nem is zárja ki, hogy az integráció egy magasabb szintje érvényesüljön.

A szociális integráció a középső szintet jelenti, ahol az együttnevelés lehet alkalmi jellegü vagy rendszeres, és főként a tanításon kívüli közös tevékenységekben nyilvánul meg. Az integráció legfejlettebb szintjének a funkcionális integrációt tekinti, amikor a diákok az órán együtt tanulnak, közös foglalkozásaik vannak. Az együttnevelés lehet részleges és teljes. Részleges funkcionális integrációt jelent, ha a különböző kategóriába sorolt diákok csak a tanítási idő egy részében, egyes foglalkozásokon vannak együtt, míg a teljes funkcionális integráció esetében egész nap és valamennyi foglalkozásra, tanórára kiterjed az együttnevelés.

A funkcionális integráció két szinten valósulhat meg: a különbség azon van, hogy az iskolában fogadják vagy befogadják (inklúzió) a tanulókat. Fogadás esetén az iskola és a pedagógus a diákot elfogadja, de nincs integrációs stratégiája az együttnevelés módszerére és stílusára. Probléma esetén hárít, a megoldást a gyógypedagógustól várja, és a személyes felelősségét hárítani igyekszik. Az inklúzió az integráció legfejlettebb szintje, amely az iskola és a szülő együttmúködésére, a szociális befogadásra, az egyéni differenciálásra, a változatos óraszervezésre és értékelési eljárásra, a szakemberek partnerségére és közös felelösségvállalására épít.

Az említett integrációs fajták és szintek mellett nem hagyható figyelmen kívül a spontán integráció lehetősége. Spontán integrációról beszélhetünk abban az esetben, ha a diák nem tudatos választás eredményeként többségei intézményben tanult, de szervezett segítséget nem kap, csak fogadják (Csányi 2001).

1. ábra: Az integráció szintjei és fajtái

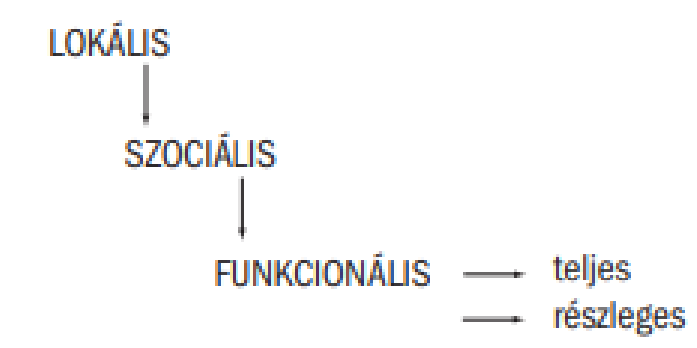


$\mathrm{Az}$ ellentétes fogalompár és típusainak ismerete segíti a szegregáció jelenéségnek, és a szegregáció és az iskolai teljesítmény, előrehaladás és a csoportközi kapcsolatok közötti összefüggések megértését.

\section{Az iskolai szegregáció a kutatási eredmények, adatok tükrében}

Kutatási eredmények igazolják, hogy hazánkban a tanulók elkülönítése már a 70 -es évektől jelen van, és a rendszerváltás követően felerősödik. A 90-es évek előtt a kötelező beiskolázás a kijelölt lakókörzetek alapján valósult meg, ennek ellenére Csanádi, Ladányi és Gerő (1978), Ladányi és Csanádi (1983) szerzőpárosoknak a 70-es években készült vizsgálatának eredményei már azt mutatták, hogy az iskolán belül és kívül informálisan, rejtetten, de jelen van az elkülönítés. Az iskolán belül a tagozatos osztályokon keresztül valósult meg az elkülönítés, míg az iskolán kívül a rejtett szegregáció intézményesült formáját a kisegítő iskolák/osztályok jelentették ebben az időszakban (Dupcsik 2012).

Csanádi, Ladányi és Gerő (1978) budapesti iskolákban vizsgálta a normál és a tagozatos osztályok tanulóinak családi hátterét, társadalmi státuszát. A tanulók 23,6\%-ánál az apa segédmunkás, illetve betanított munkás, ugyanakkor a tagozatos osztályokban ez az arány mindössze $11,2 \%$ volt, miközben a kisegítő osztályokban 51,7\%-ra nőtt az arányuk. A magasabb társadalmi státuszú, értelmiségi szülők gyermeke 7,5-ször nagyobb eséllyel kezdték meg a tanulmányaikat tagozatos osztályba, mint kisegítőbe, a roma gyerekek viszont ugyanebben a kerületben 5,5-ször nagyobb eséllyel tanultak kisegítőben (Csanádi, Ladányi és Gerő 1978: 33-40).

Szintén ugyanebben az időszakban ('70-es években) Kemény kutatási eredményei azt mutatták, hogy a kisegítő iskolákban felülreprezentált a roma tanulók aránya. Zárótanulmányában a kisegítő iskolákat gyógypedagógiai tagozatként nevezi meg. A kutató megfogalmazása szerint a cigánytelepek mellett helyezkednek el a kisegítő iskolák, amelyek tulajdonképpen cigányiskolaként funkcionálnak (Kemény 1976). Dupcsik a Kemény kutatás eredményeinek összegzéseként megállapította, hogy ,,az elvileg gyógypedagógiai ellátórendszer ezen eleme a társadalmi szegregáció eszközévé vált" (Dupcsik 2012: 246).

A 90-es évektől kezdődően az alapfokú oktatási intézmények már fogadhatják a beiskolázási körzeten kívülről érkező gyerekeket. A szülök szabad iskolaválasztása, melynek értelmében az alapfokú oktatási intézmények fogadhatják a beiskolázási körzeten kívülről érkező gyerekeket is, felgyorsította a lakóhelyi és intézményi szegregációt. Kialakultak a cigány 
és nem cigány iskolák/osztályok (Havas és Zolnay 2010), egyre erősödött az eltérő társadalmi hátterü diákok iskolai elkülönülése, szegregált oktatása (Györgyi és Kőpatakiné Mészáros 2011).

A jászladányi eset az iskolai szegregáció egyik szélsőséges példája. A 6000 lakosú nagyközség tehetősebb családjai a gyermekeket nem a helyben lévő, hanem a település közelében lévő iskolákba íratták be, melynek oka nem a színvonal, a felszereltség, az oktatási és idegen nyelvi kínálat volt, sokkal inkább az, hogy nem akarták a gyermekeiket a roma kortársaikkal egy iskolába járatni. Az önkormányzat a negatív folyamat megállítása érdekében 2003-ban megnyitotta az Antal Mihály Alapítványi Iskolát. Az igazgatónő kapacitáshiányra hivatkozva megtagadta a cigány diákok felvételét annak ellenére, hogy mindösszesen 209 tanuló iratkozott be az iskolába az engedélyezett 250 fö helyett, vagyis az iskola vezetése a 2003 szeptemberében hatályba lépett módosított közoktatási törvény szegregációt tiltó paragrafusát sem vette figyelembe. Az alapítványi iskolán keresztül megtörtént a cigány tanulók csaknem teljes közoktatási elkülönítése (Zolnay 2004).

A 2003-as vizsgálat eredményei azt mutatták, hogy minden negyedik ötödik cigány gyerek tanul olyan iskolában, ahol a romák aránya magasabb mint $40 \%$, és minden hatodik gyermek olyanban, ahol ez az arány $50 \%$ feletti, a nem roma tanulók aránya ellenben alacsony $(2,5 \%$, illetve $1,4 \%)$ az érintett iskolákban (Havas és Liskó 2005: 11). Az iskolák közötti szegregáció mellett az iskolán belüli szegregáció is gyakran alkalmazott eljárás. Az iskolán belüli szelekció azon iskolák jellemzője, ahol a hátrányos helyzetủ roma és nem roma tanulók aránya alacsony, de a diákok közötti társadalmi különbség mértéke jelentős. Minden negyedik általános iskolában müködött homogén roma és nem roma osztály, ahol a roma tanulók aránya $25 \%$ alatt volt (Havas és Liskó 2005: 20).

2004-ben az általános iskolások 3,6\%-a gyógypedagógiai osztályokban tanult. A roma általános iskolások körében ugyanez az arányt Havas, Kemény és Liskó (2002), Kemény, Janky és Lengyel (2004), és Havas és Liskó (2006) kutatási eredményei alapján Havas legalább 15\%-ra becsüli. A 2004. évi gyermekvédelmi statisztika adatai azt mutatták, hogy a gyógypedagógiai oktatásban részesülő állami gondozott diákok aránya $29 \%$ - a romák becsült arányának közel duplája - és a gyermekotthonban elhelyezettek körében mintegy két és félszerese volt (37,8\%) (Havas 2008: 129).

A hajdúhadházi eset az iskolai szegregáció egyik igazolása. A 2006-os adatok alapján Hajdúhadház önkormányzatának fenntartásában kettő általános 
iskola müködött a város 3-3 eltérö feladat-ellátási helyén. Az „Esélyt a Hátrányos Helyzetű Gyermekeknek Alapítvány" adati alapján az iskolák központi épületében a roma tanulók aránya $30 \%$ alatt volt, míg a többi iskolaépületben az arányuk meghaladta a $86 \%$-ot, sőt, kettőben homogén roma tanulók tanultak (CFCF é.n.).

Az Országos kompetenciamérésen alapuló számítások eredménye alapján 2008 és 2016 között folyamatosan emelkedik a gettóiskolák aránya. 2008-ban 10,2\% volt azoknak az általános iskolák az aránya, ahol a roma tanulók aránya 50\% feletti, 2016-ban ez az arány 14\%-ra nőtt. Ugyanebben az időszakban a gettósodó iskolák aránya mérséklődött, de továbbra is jelentős mértékü: 11,1\%-ról 9,7\%-ra csökkent azoknak az iskoláknak az aránya, ahol a roma tanulók aránya 30 és 50\% között van (Ercse 2018: 179).

Az iskolai szegregáció mérésének mutatója a szegregációs index. „Azt mutatja meg, hogy a kisebbséghez és a többséghez tartozó tanulók közötti lehetséges kontaktusok hány százaléka hiúsul meg az iskolai elkülönülés következtében" (Varga 2019: 180). Minél magasabb a szegregációs index értéke, annál nagyobb mértékü az iskolai elkülönülés a kisebbséghez és a többséghez tartozó tanulók között, azaz nem ugyanazon iskolába járnak. Az index maximumértéke abban az esetben 100, ha a kisebbséghez tartozó diákok homogén iskolába járnak, teljesen elkülönítetten tanulnak. Az index minimumértéke akkor nulla, ha minden egyes iskolában azonos arányban vannak jelen a kisebbséghez tartozó tanulók.

Az index meghatározásakor a kisebbségi státuszt három definíció alapján határozzák meg a kutatók: hátrányos helyzet $(\mathrm{HH})$, halmozottan hátrányos helyzet $(\mathrm{HHH})$ és speciális nevelési igényű (SNI). A kutatók a szegregációs indexet az általános iskolában tanuló diákok adatai alapján számolják és az iskolák közötti szegregációt mérik a mutató révén.

A 2008 és 2018 közötti időszakban a hátrányos helyzetü tanulók szegregációs indexének értéke 27,7-ről 40,0-ra, és a halmozottan hátrányos helyzetű tanulóké 26,6-ról 37,1-re emelkedett. A növekedés magyarázata részben az, hogy 2013 szeptemberétől szigorodott a hátrányos és halmozottan hátrányos helyzetü gyermekek/tanulók jogi státuszának a meghatározása, melynek eredményeként a legkevésbé hátrányos helyzetủek vesztették el a státuszukat, és jelentős mértékben csökkent a hátrányos és halmozottan hátrányos helyzetü tanulók aránya. A szakértők azt feltételezik, hogy a státuszuktól megfosztott diákok nagyobb valószínüséggel jártak az átlagosnál magasabb többségi tanulók iskoláiba, ezért a törvényi szabályozás növelte a szegregációs indexet is, függetlenül attól, hogy az iskolák tanulói 
összetételében nem történt változás. Az SNI tanulók szegregációs indexe 2008-tól 2018-ig 36,5-ről 29,1-re mérséklődött, ami kizárólag az SNI diákokat oktató iskolába járók arányának csökkenéséből ered (Varga 2019: 181)

2. ábra: Szegregációs index értéke 2008 és 2018 között

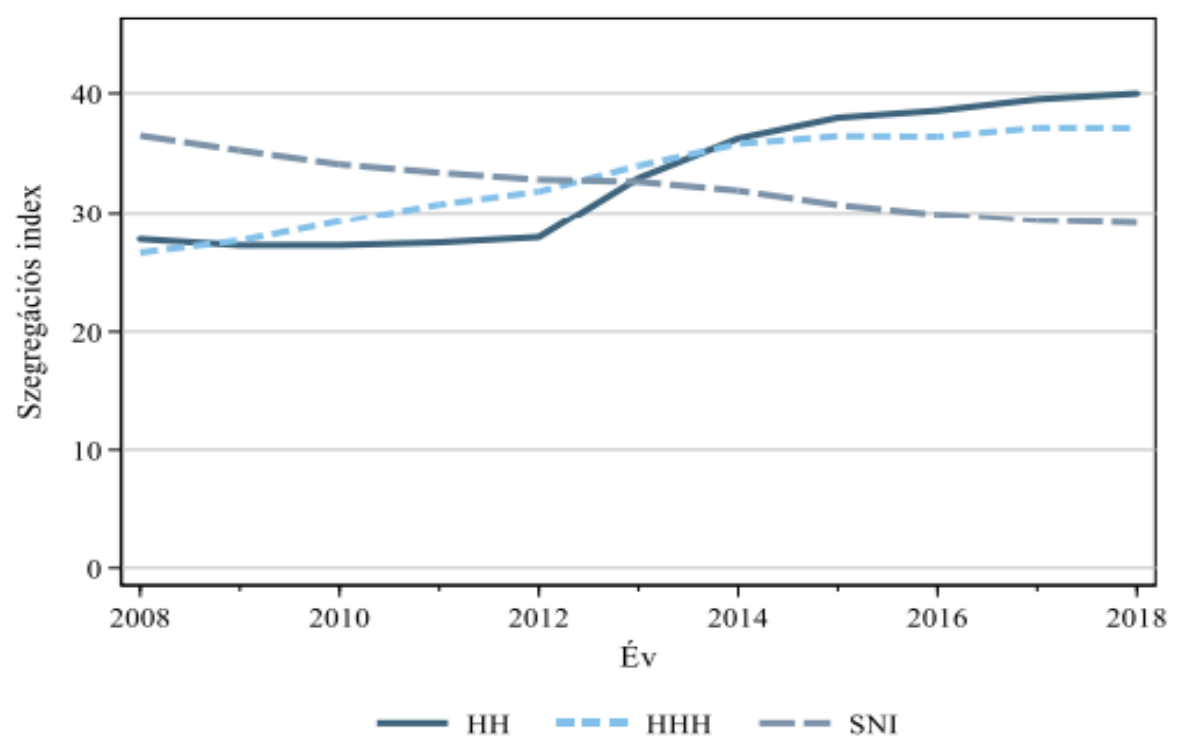

Forrás: Varga 2019: 182

Külön vizsgálták 2018-ban a városokban müködő iskolák szegregációs indexét. A szegregációs index értéke azt mutatta, hogy a hátrányos és halmozottan hátrányos helyzetü diákok a településen belül eltérő iskolába járnak. A hátrányos, halmozottan hátrányos helyzetủ diákok szegregációs indexe 10 felett volt (Varga 2019: 182-183).

A vizsgálatok azt igazolják, hogy Magyarországon a tanulók elkülönítése a társadalmi- gazdasági és az etnikai háttér alapján egyaránt erősödik, ami hatással van a diákok iskolai teljesítményére, a kognitív és nem-kognitív készségek fejlődésére és a csoportközi kapcsolatok alakulására.

\section{A szegregáció hatása az iskolai teljesítményre}

A közoktatásban kétirányú szelekció érvényesül: a magasabb társadalmi státuszú családok kiválasztják a gyermekeik számára megfelelőnek tartott elit, alapítványi - iskolákat, a magasabb státuszú iskolák pedig a számukra kívánatos gyerekeket várják, illetve kiszelektálják a nem kívánt tanulókat (Zolnay 2004). Az iskolába való belépéskor a hátrányok feltárása és kiegyenlítése, differenciált fejlesztés helyett a gyengén teljesítő diákokat 
gyakran külön osztályokba, tagozatokba, iskolákba sorolták (Nagy 2008: 54), vagy tanulmányaik alatt magántanulói státuszt ${ }^{3}$ kaptak (Török, Szekszárdi és Mayer 2011). A hatékony szelekció eredményeként akár egy egész település a hátrányos helyzetủ népesség gettójává válhatott (Reszkető, Scharle és Váradi 2010).

A szelekciót sok esetben az is elősegítette, hogy jó néhány iskola esetében már iskolakezdéskor a diákok fejlettségi szintje között jelentős különbség - az is előfordult, hogy 5 évnyi különbség - volt, amit az iskola a hagyományos képzési rend keretében nem volt képes kezelni (Nagy 2008). Sok esetben az iskolakezdést követően növekedtek a születéskori társadalmi helyzetböl fakadó és az otthonról hozott hátrányok (Reszkető, Scharle és Váradi 2010). Azokban az iskolákban, ahol magas a hátrányos helyzetű diákok aránya, a diákok már az első osztálytól kezdve gyakran gyengébb minőségủ oktatásban - rosszabb tárgyi feltételekkel, képzetlenebb tanárokkal és gyakoribb tanárhiánnyal - részesülnek, ami a hátrányok halmozódásához vezet, és nő a diákok közötti teljesítményszakadék (Havas 2008, Kertesi és Kézdi 2009).

A PIRLS (olvasás) és a TIMSS (matematika, természettudomány) nemzetközi összehasonlító vizsgálatok célja annak feltérképezése, hogy milyen a diákok tárgyi tudása és milyen kognitív készségekkel rendelkeznek a tanulók egy adott területen. A PIRLS felmérés három területre fókuszál: az olvasás céljára, a gondolkodási müveletekre, az olvasási szokásokra és attitüdökre és a szövegértés kognitív készséget méri. A TIMMS matematikai felmérés tartalmi területe 4. osztályban a számok, a geometriai alakzatok és a mérés, 8. osztályban pedig a számok, az algebra, a geometria, az adat és a valószínűség. Mindkét évfolyamon három kognitív területet mér: az ismeretet (tények, fogalmak és eljárások), az alkalmazást (tudás alkalmazásának képessége és a feladat megoldásához vagy a kérdés megválaszolásához szükséges fogalmi megértés képessége) és az értelmezést (ismeretlen szituációk, összetett szövegkörnyezet, többlépéses feladatok megoldása) (Balázsi, Szabó és Szalay 2012). Ezek a vizsgálatok alkalmasak a korai teljesítményszakadékok feltárására, a tanulás és a tanítás eredményességének elemzésére. A TIMSS felmérések negyedik osztályban a PIRLS 2011-es olvasás (Balázsi, Szabó és Szalay 2012) és a TIMSS 2011-es, 2015-ös matematika mérések (Mullis és mtsai 2016) eredményei azt igazolják, hogy a magyar diákok körében nagy a teljesítményszakadék, sőt, a mérésben részt

3 2010-ben a magántanulói státussal rendelkező gyerekek 48\%-a hátrányos, és 35\%-a halmozottan hátrányos helyzetü és a roma tanulók aránya négyszerese a nem roma tanulóknak (Török, Szekszárdi és Mayer 2011: 292-293). 
vevő európai országok között a legnagyobb. Fejes és Szücs (2018) megállapítása szerint az említett két nemzetközi vizsgálat eredményei összefüggnek a szegregációval, az iskolák közötti jelentős mértékben eltérő minőségi szolgáltatással.

A szelekció az iskolába lépést követően tovább erősödik. Egyes iskolákban az ötödik osztálytól felfelé emelt szintü tanulócsoportokat alakítanak ki, és a társadalmi szelekció logikáját követve elkülönül a továbbtanulásra felkészítő és a felzárkóztató képzés. A negyedik és hatodik osztályt követően föként a magasabb társadalmi státuszú gyermekek azok, akik nyolc-, illetve hatosztályos gimnáziumban folytatják tovább tanulmányaikat. Ez a folyamat leginkább azokat az iskolákat érinti erőteljesen, amelyekben felülreprezentált a hátrányos helyzetű tanulók aránya, és ezzel összefüggésben alacsony az oktatás színvonala (Havas 2008). A leírtak érvényességét napjaink statisztikai adatai is megerősítik (Lásd: 3. sz. ábra). 2018-ban a hátrányos helyzetü tanulók aránya az általános iskolában $14,1 \%$, ellenben a 6 és 8 osztályos gimnáziumokban nem éri el az 1\%-ot. Az alapfokú képzésben tanuló hátrányos és halmozottan hátrányos helyzetü tanulók arányának különbsége megegyezik az egyes programtípusok esetében (Varga 2019: 23).

A 2007 és 2011-es nyolcadikos TIMSS-mérés megállapítása szerint az általános iskolák felső tagozata nem módosította a teljesítménykülönbségeket, sokkal inkább az elsőtől a negyedik osztályig kialakult teljesítményszakadékot görgette tovább a középfokú tanulmányok idejéig. Ugyanakkor a 2015-ös mérés szerint az általános minőségromlás miatt a felső tagozat már tovább erősíti a korábban kialakuló nagymértékü teljesítménykülönbséget, melynek következménye a jelentős mértékü középfokú szelekció (Mullis és mtsai 2016).

A nyolcadik osztály elvégzését követően a diákok eltérő középfokú oktatási intézményben folytatják tovább tanulmányaikat. A halmozottan hátrányos helyzetủ tanulók és különösen a romák körében az érettségit adó középiskolába jelentkezők aránya kismértékben nö, miközben a nyolcadik osztályos évfolyam nagytöbbsége tanul tovább érettségit biztosító középiskolákban és a szakképzetlen, alacsony iskolázottságú szülők gyermekinek gyüjtőhelye marad a szakiskola, a jelenlegi szakközépiskola. A 2018-as adatok is azt igazolják, hogy a jelenlegi szakközépiskolákban a legmagasabb a hátrányos $(19,3 \%)$ és a halmozottan hátrányos helyzetü diákok (11,3\%) aránya, és a körükben a legalacsonyabb a szakgimnáziumban és a 4 osztályos gimnáziumban tanulók aránya. A halmozottan hátrányos helyzetủ tanulók 
körében a szakgimnazisták aránya 2,1\%, miközben a 4 osztályos gimnáziumba járók aránya alig valamivel több, mint 1\% (Varga 2019: 23-24). Az alacsony színvonalú szakiskolák, jelenlegi szakközépiskolák fogadják főként a tudásbeli és kompetenciák hiányával küzdő olykor funkcionális analfabéta tanulókat. Ezeket az intézményeket alacsony követelmény és képzési színvonal jellemzi (Liskó 2005, 2006, Havas 2008). Pálosi és R. Fedor 2017es kutatási eredményei is megerősítették, hogy a gimnáziumok fogadják a magasan kvalifikált, átlag feletti tanulmányi eredménnyel rendelkező jó képességű gyermekeket (Pálosi és R. Fedor 2017).

3. ábra: A hátrányos helyzetü $(\mathrm{HH})$ és halmozottan hátrányos helyzetü (HHH) tanulók aránya programtípusok szerint (2018)

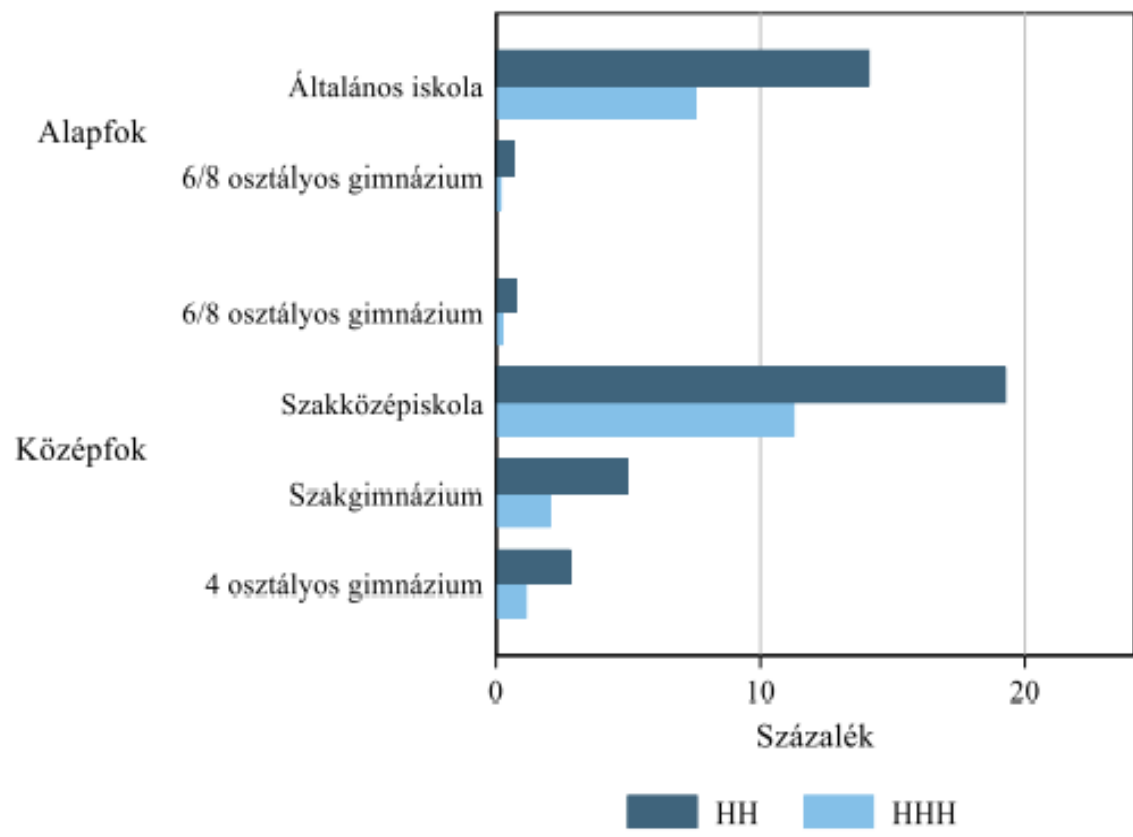

Forrás: Varga 2019: 24

A 2017. évi országos kompetenciamérések ${ }^{4}$ eredménye szerint a szakiskolák/jelenlegi szakközépiskolák 10. osztályos tanulóinak a kompetenciaszintje, kognitív készségei átlagosan nem érik el a hatodik osztályosok szintjét, és a 8 . és 10 . évfolyamon sem javulnak az eredmények, vagyis az iskolatípus nem hatékony a diákok kognitív alapkészségeinek a fejlesztésében (Oktatási és Képzési Figyelö 2018: 4). A megszerzett alacsony

\footnotetext{
${ }^{4}$ Az Országos kompetenciamérések hatodik, nyolcadik és a tizedik osztályos diákok kognitív alapkészségeit és készségeit méri a matematikai és a szövegértési feladatokon keresztül (Balázsi et al. 2016).
} 
értékủ bizonyítvánnyal való elhelyezkedés lehetősége korlátozott a munkaeröpiacon (Havas és Liskó 2006).

Az OECD 15 éves korosztályt (7.-8.-9.-10. osztályos tanulókat) mérő PISAvizsgálatok megállapítása szerint: a hazai iskolarendszerben rendszerszinten állandósultak a szelekciós folyamatok. A diákok átlagteljesítménye szövegértésből, matematikából és természettudományból - a nemzetközi átlag alatt van (OECD 2016). A felmérésben részt vevő országok közül hazánkban a legnagyobb az iskolák közötti teljesítményszakadék mértéke a 2000-res évek óta lezajlott hét vizsgálat mindegyikében (OECD 2001, 2004, 2007a, 2007b, 2010a, 2010b, 2013, 2016, 2019, Vári és mtsai 2002), az egyes iskolák eltérő mértékü szolgáltatást nyújtanak. Továbbá az első vizsgálatok eredményei is már azt mutatták, hogy a tanulók teljesítményét a családi háttér nagymértékben befolyásolja (OECD 2001, 2004, 2007a, 2007b, 2010a, 2010b, 2013, 2016, 2019). Radó (2018) arra hívja fel a figyelmet, hogy az iskolarendszer szelektivitása miatt a családi háttér hatása jellemzően nem közvetlenül, hanem az iskola státuszán keresztül befolyásolja a diákok teljesítményét ${ }^{5}$. A tanulók nagy többsége homogén iskolában tanul tovább, ami a teljesítményükre jelentős hatással van (Radó 2018). A 2015-ös felmérés eredménye szerint a középfokú iskolák közül a szakiskolákba/jelenlegi szakközépiskolákba járók teljesítettek a legrosszabbul (PISA 2016), ahol a legnagyobb arányban tanulnak a hátrányos helyzetü, roma diákok.

Az alacsony társadalmi státuszú, hátrányos helyzetü, roma tanulókat fogadó szelektív, szegregált iskolákban alacsony az oktatás színvonala, negatív hatásai a tanulók teljesítménykülönbségében, a kognitív készségek lemaradásában is megmutatkoznak.

\section{A szegregáció hatása a csoportközi kapcsolatokra}

Az oktatási szegregáció hatásával foglalkozó szakirodalom, és a nemzetközi (PISA, TIMSS, PIRLS) és hazai felmérések (Országos Kompetenciamérések) jelentős része a szegregáció tanulmányi eredményekre gyakorolt hatására fókuszált és kevesebb figyelem irányult arra, hogy a szegregált oktatás negatívan hat a csoportközi kapcsolatokra.

A szegregált oktatás keretében a különböző társadalmi csoportokhoz tartozó, illetve etnikai hátterủ diákok között kevesebb a kontaktus lehetősége, mint az integrált oktatás keretében. Az iskola biztosítja a társadalom

${ }^{5}$, a tanulói ESCS indexek iskolai szintü aggregációja állitja elő az iskolák státuszindexét” (Radó 2018: 33) 
jövendőbeli felnőtt tagjai részére, hogy hosszú évekig tartó stabil közösségben a közvetlen személyes kapcsolatokon keresztül tapasztalatot, információt szerezzen az eltérő társadalmi, etnikai csoportokhoz tartozó diákokról, felnőttekről, de az iskolai elkülönülés mindezt meggátolja (Kertesi és Kézdi 2009).

A marginalizált, hátrányos helyzetü, roma diákok a leginkább azok, akik lakóhelyi és társadalmi izoláció körülményei között élnek és az iskola biztosíthatja számukra annak a lehetőségét, hogy személyes ismertséget, kapcsolatot alakítsanak ki a középosztály tagjaival. Hajdu, Kertesi és Kézdi 2010-ben 77 település 85 általános iskolájában vizsgálta a roma és nem roma tanulók közötti kapcsolatok (barátságok és elutasítások) kialakulását meghatározó összefüggéseket. A vizsgálat eredményei azt mutatták, hogy az interetnikus barátságok kialakulására részben a tanulók iskolai eredményei vannak hatással, részben az, hogy a diákok milyen mértékben vannak jelen az osztályban egymás társaságának. A jó tanuló roma gyerekeknek jellemzően több a nem roma barátjuk és a nem roma ellenségük is kevesebb, mint a rosszul tanuló roma diáktársaiknak. A kutatók megállapítása szerint a hatás erősségéhez hozzájárul, hogy a diákok egymást jól ismerik az osztályközösségekben az általános iskolában eltöltött nyolc év alatt (Hajdu, Kertesi és Kézdi 2015).

Az azonos iskolában tanuló diákok csoportközi kontaktusok gyakoriságát segíti az iskolaidőn túli, közösen eltöltött szabadidős tevékenységek növelése (Wells és Crain 1997). Jó példa erre, hogy az etnikailag vegyes futballcsapatok, diákzenekarok és iskolai klubok lehetőséget teremtenek az általános és középiskolás diákok számára, hogy az eltérő faji/etnikai csoport tagjait önálló egyénekként, és ne a faji sztereotípiák megtestesítőjének tekintsék, azaz a szabadidős tevékenységek során létrejövő laza kapcsolatok áthidalják a faji/etnikai választóvonalat (Clotfelter 2004).

Az integrált iskolai körülmény sem garancia arra, hogy az alacsony társadalmi státuszú diákok tartós barátságokat alakítanak ki az iskolai közösségben, vagy akár az osztálytársak között, de a közös iskolai múltból kiindulva lehetőségük nyílik a társadalmi izolációból kivezető gyenge kapcsolatok megalapozására (Granovetter 1983, Kertesi és Kézdi 2009). A gyenge kapcsolatok is erőforrásként szolgálhatnak a fiatalok felnőtt élete során, melynek két fö kitüntetett területének a továbbtanulást és az álláskeresését nevezik meg. A továbbtanulási lehetőségekről és az álláshelyekről való információhoz való hozzáférés esélye korlátozott a társadalmi elszigeteltségben élők körében, mert nagyrészt a környezetükben 
élő kortársakkal, családtagokkal alakítanak ki erős kapcsolatokat, aminek az a következménye, hogy a meglévő kapcsolataik a helyi közösségbe zárják az ott élőket, ezáltal kimaradnak a magasabb társadalmi státusz felé vezető gyenge kapcsolatok előnyétől (Granovetter 1983, Kertesi és Kézdi 2009).

Az eltérő társadalmi és etnikai csoportok közötti társas kapcsolatok esélyének növekedése és a társadalmi kohézió erősödése legalább olyan fontos és hasznos a társadalmi integráció megvalósulása céljából, mint az iskolai teljesítmény növekedése.

\section{Összegzés}

A középfokú oktatási intézmények között a szakiskolában, jelenlegi szakközépiskolában tanuló föként hátrányos helyzetü, roma diákoknak a legalacsonyabbak a kognitív készségei, miközben az esetükben a legnagyobb a korai iskolaelhagyás és a munkaerőpiacról való kiszorulás esélye. Ugyanakkor a kognitív készségdeficittel rendelkező szakiskolát, jelenlegi szakközépiskolát végzett fiataloknak sem sokkal jobb a helyzete a munkaerőpiacon. A bizonyítvánnyal, szakmával rendelkező fiatalok fele szakképzetlen vagy félig képzett munkaerőként talál magának munkát. A dolgozó fiatalok között is 2,4\%-ról 6,2\%-ra nött a 2011 és a 2016 közötti időszakban a közmunkaprogramban foglalkoztatottak aránya. A szakközépiskolát/szakgimnáziumot végzett fiataloknak a legjobbak a kognitív készség eredményei és a munkaerőpiacon a középfokú végzettséggel rendelkezők közül a legelőnyösebb helyzetben vannak (Oktatási és Képzési Figyelő 2018: 7). Az alacsony iskolai végzettség, a szakképzettség hiánya és a roma etnikumhoz tartozás csökkenti a munkaerőpiacon való elhelyezkedés és a tartós munkaerőpiaci helytállást esélyét, és növeli a tartós munkanélküliség, a jövedelmi szegénység és a társadalmi kirekesztődés kockázatát (Láczay és R. Fedor 2017, R. Fedor és Pálosi 2017, 2018, R. Fedor et.al. 2021).

Magyarországon a tanulók elkülönítése a társadalmi- gazdasági és az etnikai háttér alapján egyaránt erősödik, ugyanakkor az oktatási szegregáció és integráció kérdésköre gyakran vita téma, mindkettő mellett számos érvet és ellenérvet hoznak fel. A homogén tanulócsoport előnye (pl. a gyenge nem tart a lemaradástól és a tehetséges nem kerül parkolópályára) és hátránya (pl. nincs húzóerő, nem lép interakcióba intellektuálisabb társaival) mellett is szólnak érvek, ugyanakkor a kutatási tapasztalatok a heterogén összetételt preferálják mind a tanulmányi teljesítmény, a személyiségfejlődés, a csoportközi és társas kapcsolatok és készségek, valamint a szocializáció és a közösségbe való 
beilleszkedés szempontjából (Tóth 1996, Bihari és Csoba 2018). Az iskolai szelekció csökkentése céljából több hazai kísérlet is történt, ennek ellenére a hazai oktatási rendszer szelektivitása, szegregáltsága nem csökkent, továbbra is napjaink aktuális problémája, ami az oktatási rendszeren kívül a gazdaság fejlettségét és versenyképességét, az alacsony társadalmi státuszú, hátrányos helyzetü, roma fiatalok iskolai és munkaerőpiaci esélyeit, társadalmi integráltságát is kedvezőtlenül befolyásolják.

\section{Irodalom}

1. Arató, F., Horváth, A., Varga, A. (2005): Hatékony együttnevelés az iskolában - tréneri kézikönyv. Budapest, suliNOVA Kht.

2. Balázsi, I., Szabó, V., Szalay, B. (2005): A matematikaoktatás minősége, hatékonysága és az esélyegyenlőség. A PISA 2003 nemzetközi tudásmérés magyar eredményei. Új Pedagógiai Szemle, 11.

Letöltés helye: https://folyoiratok.oh.gov.hu/uj-pedagogiai-szemle/amatematikaoktatas-minosege-hatekonysaga-es-az-eselyegyenloseg

3. Bihari, I., Csoba, J. (2018): „Az iskolán túl... A tanodák szerepe a hátrányos helyzetü tanulók társadalmi integrációjában. Metszetek (7), 2: 3-27. Letöltés helye: http://metszetek.unideb.hu/files/metszetek_201802_01.pdf

4. CFCF (é.n.): Hajdúhadházi szegregációs ügy. Letöltés helye: http://cfcf.hu/hajd\%C3\%BAhadh\%C3\%A1ziszegreg\%C3\%A1ci\%C3\%B3s-\%C3\%BCgy

5. Clotfelter, Ch. T. (2004): After Brown. The rise and retreat of school desegregation. Princeton and Oxford, Princeton University Press.

6. Csanádi, G., Ladányi, J., Gerő, Zs. (1978): Az általános iskolai rendszer belső rétegződése és a kisegítő iskolák. Valóság, 6: 30-44.

7. Csányi, Y. (2001): Különtámogatás: szegregáltan vagy integráltan. Educatio, 2: 232-243. Letöltés helye:

http://folyoiratok.ofi.hu/sites/default/files/article_attachments/csanyi_y_ 01_02.pdf

8. Csapó, B., Molnár. Gy., Kinyó, L. (2009): A magyar oktatási rendszer szelektivitása a nemzetközi összehasonlító vizsgálatok eredményeinek tükrében. Iskolakultúra (19), 3-4: 3-13. 
9. Dupcsik, Cs. (2012): Az integráció fogalma a társadalomtudományos és a laikus társadalomképekben az oktatási integráció példáján keresztül. In: Kovách, I., Dupcsik, Cs., P. Tóth, T., Takács, J. [szerk.]: Társadalmi integráció a jelenkori Magyarországon. Tanulmányok. MTA Társadalomtudományi Kutatóközpont (Szociológiai Intézet), Argumentum Kiadó: 243-261. Letöltés helye: http://mek.oszk.hu/12700/12706/12706.pdf

10. Ercse, K. (2018): Az állam által ösztönzött, egyházasszisztált szegregáció mechanizmusa. In: Fejes, J. B., Szücs, N. [szerk.]: Én vétkem. Helyzetkép az oktatási szegregációról. Szeged, Motiváció Oktatási Egyesület: 177200. Letöltés helye: http://mek.oszk.hu/18200/18263/18263.pdf

11. Fejes, J. B., Szücs, N. (2018): Az oktatási integráció ügye a 2010-es évek végén. In: Fejes, J. B., Szűcs, N. [szerk.]: Én vétkem. Helyzetkép az oktatási szegregációról. Szeged, Motiváció Oktatási Egyesület: 11-30.

Letöltés helye: http://mek.oszk.hu/18200/18263/18263.pdf

12. Fónai, M. (2020): Roma/cigány közösségek. In: Pusztai, G. [szerk.]: Nevelésszociológia: Elméletek, közösségek, kontextusok. Debrecen, Debreceni Egyetemi Kiadó: 177-205.

13. Granovetter, M. S. (1983): The strength of weak ties: a network theory revisited. Sociological Theory, 1: 201-233. Letöltés helye: https://www.jstor.org/stable/202051?seq=1\#metadata_info_tab_contents

14. Fiáth, T. (2002): A magyarországi roma népesség általános iskolai oktatása. In: Babusik, F. [szerk.]: A romák esélyei Magyarországon: Aluliskolázottság és munkaerőpiac - a cigány népesség esélyei Magyarországon. Budapest, Kávé Kiadó - Delphoi Consulting: 11-70.

15. Gerő, Zs., Csanádi, G., Ladányi, J. (1996): A „megszüntetve megőrzött” gyogyó. A kisegítő iskola egy nyomonkövetéses vizsgálat tükrében. Kritika, 7: 8-12.

16. Györgyi, Z., Köpatakiné Mészáros, M. (2011): Oktatási egyenlőtlenségek és sajátos igények. In: Balázs, É., Kocsis, M., Vágó, I. [szerk.]: Jelentés a magyar közoktatásról 2010. Budapest, Oktatáskutató és Fejlesztő Intézet: 363-395. Letöltés helye: http://mek.oszk.hu/12800/12893/12893.pdf

17. Hajdu, T., Kertesi, G., Kézdi, G. (2015): High-Achieving Minority Students Can Have More Friends and Fewer Adversaries. Budapest, Budapest Eorking Paper on the labour market. Letöltés helye: http://www.econ.core.hu/file/download/bwp/bwp1507.pdf 
18. Havas, G. (2008): Esélyegyenlőség, deszegregáció. In: Fazekas, K., Köllő, J., Varga, J. [szerk.]: Zöld könyv a magyar közoktatás megújításáért. Budapest, Ecostat: 121-138. Letöltés helye: https://mek.oszk.hu/08200/08222/08222.pdf

19. Havas, G., Kemény, I., Liskó, I. (2002): Cigány gyerekek az általános iskolában. Oktatáskutató Intézet, Budapest, Új Mandátum Kiadó.

20. Havas, G., Liskó, I. (2006): Óvodától a szakmáig. Oktatáskutató Intézet, Budapest, Új Mandátum Kiadó.

21. Havas, G., Liskó, I. (2005): Szegregáció a roma tanulók általános iskolai oktatásában. Budapest, Felsőoktatási Kutatóintézet.

22. Hermann, Z., Horn, D., Kádár, A., Németh, Sz., Papp, Z. A., Székely, Á. (2009): Irányelvek a roma tanulók szegregált oktatásának felszámolására Oktatáspolitikai tanulmány. Oktatáskutató és Fejlesztő Intézet. Letöltés helye: http://www.ofi.hu/tudastar/esely-egyuttnevelesre/hermann-zoltan-horn

23. Havas, G., Zolnay, J. (2010): Az integrációs oktatáspolitika hatásvizsgálata. Kutatási beszámoló, Kézirat.

24. Jönsson, T. (1993): SpecialNeeds Education. UNESCO, Regional Seminarson Policy. Planning and Organization of Education of Children and Young People with Special Needs. Paris.

25. Kemény, I. (1976): Beszámoló a magyarországi cigányok helyzetével foglalkozó, 1971-ben végzett kutatásról. Budapest, MTA Szociológiai Kutató Intézet.

26. Kemény, I., Janky, B., Lengyel, G. (2004): A magyarországi cigányság, 1971-2003. Budapest, Gondolat-MTA Etnikai-nemzeti Kisebbségkutató Intézet.

27. Kertesi, G., Kézdi, G. (2012): A roma és nem roma tanulók teszteredményei közti különbségekröl és a különbségek okairól. Budapesti Közgazdaságtani Füzetek. Letöltés helye: http://www.econ.core.hu/file/download/bwp/bwp1205.pdf

28. Kertesi, G., Kézdi, G. (2005): Általános iskolai szegregáció, I. rész. Okok és következmények. Közgazdasági Szemle, LII. évf., április: 317-355.

29. Kertesi, G., Kézdi, G. (2009): Általános iskolai szegregáció Magyarországon az ezredforduló után. Közgazdasági Szemle, LVI, november: 959-1000. Letöltés helye:

http://epa.oszk.hu/00000/00017/00164/pdf/1_kertesi-kezdi.pdf

30. Ladányi, J., Csanádi, G. (1983): Szelekció az általános iskolában. Budapest, Magvető Kiadó. 
31. Láczay, M., R. Fedor, A. (2017): A szabolcs-szatmár-beregi fiatalok bizalmi kapcsolatainak bemutatása kockázati tényezők elemzése alapján. Prediktorok és protektorok egy vizsgálat adatbázisának több dimenziós elemzésében. In: Fábián, G., Szoboszlai, K., Hüse, L. [szerk.]: A társadalmi periférián élő gyermekek és fiatalok rizikómagatartásának háttere. Nyíregyháza, Periféria Egyesület: 73-90.

32. Liskó, I. (2009): A hátrányos helyzetủ tanulók oktatásának minősége. Letöltés helye: http://ofi.hu/tudastar/hatranyos-helyzetu

33. Liskó, I. (2005): A roma tanulók középiskolai továbbtanulása. Budapest, Felsőoktatási Kutatóintézet.

Letöltés helye: https://mek.oszk.hu/09800/09847/09847.pdf

34. Liskó, I., Havas, G. (2005): Szegregáció a roma tanulók általános iskolai oktatásában. Budapest, Felsőoktatási Kutatóintézet.

35. Mullis, I. V. S., Martin, M. O., Foy, P., Hooper, M. (2016): TIMSS 2015 International Results in Mathematics. TIMSS \& PIRLS International Study, Retrieved from Boston College. Letöltés helye:

http://timssandpirls.bc.edu/timss2015/international-results/wpcontent/uploads/filebase/full\%20pdfs/T15-International-Results-inMathematics.pdf

36. Nagy, J. (2008): Az alsó tagozatos oktatás megújulása. In: Fazekas, K., Köllö, J., Varga J. [szerk.]: Zöld könyv: A magyar közoktatás megújításáért 2008. Budapest, ECOSTAT, Miniszterelnöki Hivatal: 2008: 53-69.

37. OECD (2007b): Evidence in education: Linking research and policy. Paris, OECD. Letöltés helye:

http://www.oecd.org/education/ceri/evidenceineducationlinkingresearcha ndpolicy.htm\#1

38. OECD (2001): Knowledge and skills for life. First results from the OECD Program for International Students Assessment (PISA) 2000. Paris, OECD. Letöltés helye:

http://www.oecd.org/education/school/programmeforinternationalstudent assessmentpisa/33691620.pdf 
39. OECD (2004): Learning for tomorrow's world. First results from PISA 2003. Paris OECD. Letöltés helye:

https://www.oecd.org/education/school/programmeforinternationalstude ntassessmentpisa/34002216.pdf

40. OECD (2007a): PISA 2006: science competencies for tomorrow's world. Executive summary. Paris, OECD. Letöltés helye:

https://www.oecd.org/unitedstates/39722597.pdf

41. OECD (2010a): PISA 2009 results: Executive summary. Paris, OECD. Letöltés helye: https://www.oecd.org/pisa/pisaproducts/46619703.pdf

42. OECD (2010b): PISA 2009 results: Overcoming social background Equity in learning opportunities and outcomes (Volume II). Paris, OECD. Letöltés helye: https://www.oecd.org/pisa/pisaproducts/48852584.pdf

43. OECD (2013): PISA 2012 results: Excellence through equity: Giving every student the chance to succeed (Volume II). PISA. Paris, OECD Publishing. Letöltés helye:

https://www.oecd.org/pisa/keyfindings/pisa-2012-results-volume-II.pdf

44. OECD (2016): PISA 2015 results (Volume I): Excellence and equity in education. PISA. Paris, OECD Publishing.

45. OECD (2019): PISA 2018 Insights and Interpretations. Letöltés helye: https://www.oecd.org/pisa/PISA\%202018\%20Insights\%20and\%20Interp retations\%20FINAL\%20PDF.pdf

46. Oktatási és Képzési Figyelő 2018 Magyarország (2018): Európai Bizottság, Oktatásügyi és Kulturális Főigazgatóság. Letöltés helye: https://ec.europa.eu/education/sites/education/files/document-librarydocs/et-monitor-report-2018-hungary_hu.pdf

47. Ostorics, L., Szalay, B., Szepesi, I., Vadász, Cs. (2016): PISA 2015. Összefoglaló jelentés. Oktatási Hivatal. Letöltés helye:

https://www.oktatas.hu/pub_bin/dload/kozoktatas/nemzetkozi_meresek/p isa/PISA2015_osszefoglalo_jelentes.pdf

48. Pálosi, R., R. Fedor, A. (2017): A tanulási motivációk és a munkaerőpiaci elvárások összefüggései. Különleges Bánásmód, 4.: 51-63. Letöltés helye: http://real.mtak.hu/81896/1/KB_2017_4_Palosi.pdf

49. PISA 2015 Jelentés (2016). Budapest, Oktatási Hivatal. Letöltés helye: https://www.oktatas.hu/pub_bin/dload/kozoktatas/nemzetkozi_meresek/p isa/PISA2015_osszefoglalo_jelentes.pdf 
50. R. Fedor, A., Balla, P. (2019): Foglalkoztatási helyzetkép a telepi körülmények között élő nyíregyházi romák körében. Acta Medicinae et Sociologica, 10.: 32-44. Letöltés helye:

https://ojs.lib.unideb.hu/ams/article/view/4521/4320

51. R. Fedor, A., Láczay, M., Balogh, E. (2021): Mit tehetünk a lappangó tehetségekért? Ajánlások mentortanárok részére. In: Fábián, G., Fedor, A., Hüse, L., Szoboszlai, K. [szerk.] Mentori kézikönyv: Szociális munka Duális képzés mentorainak. Nyíregyháza, Debreceni Egyetem Egészségügyi Kar: 73-90.

52. R. Fedor, A., Pálosi, R. (2018): A fiatalok pályaorientációs döntései az iskola és a családi háttér tükrében. Tudásmenedzsment, 1: 52-61. Letöltés helye:

https://kpvk.pte.hu/sites/kpvk.pte.hu/files/files/EKONYVEK/xix1szam.p df\#page $=52$

53. R. Fedor, A. (2021): Job satisfaction in Hungary - comparative study. Economics and Sociology, 14(2), 331-349. doi:10.14254/2071789X.2021/14-2/18

54. Radó, P. (2018): A közoktatás szelektivitása mint a roma szegregáció általános kontextusa. In: Fejes, J. B., Szücs, N. [szerk.]: Én vétkem. Helyzetkép az oktatási szegregációról. Szeged, Motiváció Oktatási Egyesület: 31-56. Letöltés helye:

http://mek.oszk.hu/18200/18263/18263.pdf

55. Reszkető, P., Scharle, Á., Váradi, B. (2010): Az esélyegyenlőségi és integrációs kiemelt projekt külső értékelése. Budapest, Budapest Szakpolitikai Elemzö Intézet. Letöltés helye:

http://budapestinstitute.eu/uploads/BI_OKM_tamop331_ertekeles_FINA L_corr.pdf

56. Szűcs, N. (2010): Többiskolás településeken zajló közoktatási deszegregációs programok sikerkritériumai. Doktori $(\mathrm{PhD})$ értekezés. Pécs, Pécsi Tudományegyetem „Oktatás és társadalom” Neveléstudományi Doktori Iskola. Letöltés helye: https://pea.lib.pte.hu/bitstream/handle/pea/5281/szucs-norbert-phd2012.pdf? sequence $=1 \&$ isAllowed $=y$ 
57. Tóth, L. (1996): Csoportfolyamatok az osztályban. In: Balogh, L., Bugán, A., Kovács, Z., Tóth, L. [szerk.]: Fejezetek az alkalmazott lélektan köréből. Debrecen, Második, átdolgozott kiadás. A KLTE Pszichológiai Intézetének kiadványa: 149-160.

58. Török, B., Szekszárdi, J., Mayer, J. (2011): Az iskolák belső világa. In: Balázs, É., Kocsis, M., Vágó, I. [szerk.]: Jelentés a magyar közoktatásról 2010. Budapest, Oktatáskutató és Fejlesztő Intézet: 273-294.

Letöltés helye: http://mek.oszk.hu/12800/12893/12893.pdf

59. Vári, P., Auxné Bánfi, I., Felvégi, E., Rózsa, Cs., Szalay, B. (2002): Gyorsjelentés a PISA 2000 vizsgálatról. Új Pedagógiai Szemle, 52, 1: 38-65.

60. Varga, J. (2019): A közoktatás indikátorrendszere 2019. Budapest, Közgazdaság- és Regionális Tudományi Kutatóközpont Közgazdaságtudományi Intézet. Letöltés helye: https://www.mtakti.hu/wpcontent/uploads/2020/01/A_kozoktatas_indikatorrendszere_2019.pdf

61. Wells, A. S., Crain, R. L. (1997): Stepping over the color line. AfricanAmerican students in white suburban schools. New Haven, CT, Yale University Press.

62. Zolnay, J. (2004): A romapolitika sarokpontjai és finanszírozása. Múhelytanulmány 8 . Budapest, Európai Összehasonlító Kisebbségkutatások Közalapítvány. Letöltés helye:

http://miris.eurac.edu/mugs2/do/blob.pdf?type=pdf\&serial=1123849855 407 